Note

\section{A Ten Minute Procedure for Transformation of Saccharomyces cerevisiae}

\author{
David KeszenMan-Pereyra* \\ and Kotaro HIEDA \\ Biophysics Laboratory, Department of Physics, \\ Rikkyo University, Nishi-Ikebukuro 3-34-1, \\ Toshimaku, Tokyo 171, Japan
}

Received April 21, 1989

Current procedures for DNA-mediated transformation of Saccharomyces cerevisiae use batch cultures as a source of recipient cells and more than $2 \mathrm{hr}$ of manipulations. ${ }^{1)}$ Recently, we reported a procedure that uses cells growing on solid agar media. ${ }^{2)}$ The advantages of this procedure are multifold: a) it is speedy as there is no need of batch cultures; b) it is cheap and technically simple to perform; c) it is applicable to a variety of yeast strains; d) yeast cells derived from plates stored at $4^{\circ} \mathrm{C}$ can be used although they are less transformable than fresh cells.

Here we describe a simplification of our transformation procedure in which the incubation was reduced from $60 \sim$ $120 \mathrm{~min}$ to only $5 \mathrm{~min}$. We assayed conditions which allowed the recovery of transformants for a variety of strains and DNA preparations. All manipulations can be done in approximately $10 \mathrm{~min}$.

The $S$. cerevisiae strains DKKHAC2 (MATa ura3-52 leu2-3 leu2-112 lys2-801 trpl his3 ade2-1 $\left.R A D^{+}\right)$and DKKHr31 (MAT\& ura3-52 leu2-3 leu2-112 trpl his3 rad2-I) were used as hosts. The circular plasmid YCp193) (pBR322, ARS1,CEN4,TRP1,URA3) and the linear plasmid LYTC-2 ${ }^{4}$ (YCp19, EcoRI terminal restriction fragment from Tetrahymena macronuclear rDNA) were used as transforming DNA.

The following buffers were used. Tris buffer was $10 \mathrm{~mm}$ Tris- $\mathrm{HCl}$ (pH 7.5). Transformation buffer (TBT) was prepared by mixing $0.15 \mathrm{ml}$ of triacetin with $\mathrm{Iml}$ of Tris buffer containing $0.2 \mathrm{M}$ lithium thiocyanate, $1 \mathrm{~mm}$ magnesium acetate, and $0.2 \mathrm{~mm}$ calcium acetate.

The transformation procedure was done as follows: to an 1.5-ml Eppendorf tube, $115 \mu$ l of TBT, a loopful of yeast cells from a YPAD ${ }^{5 y}$ agar plate incubated for 4 days at $30^{\circ} \mathrm{C}$, DNA preparation, and 4 volumes of $\mathrm{PEG}$ solution $(70 \mathrm{~g}$ of polyethylene glycol- 4000 in $100 \mathrm{ml}$ of Tris buffer) were added, vortexed, and incubated for $5 \mathrm{~min}$ at either $30^{\circ} \mathrm{C}$ of $42^{\circ} \mathrm{C}$ in a water bath. Then, $800 \mu \mathrm{l}$ of Tris buffer was added and after centrifugation the cells were
Table I. Transformation of Whole Yeast Cells by the 10 min Transformation Procedure

\begin{tabular}{|c|c|c|c|}
\hline \multirow[b]{2}{*}{ Strain $^{c}$} & \multirow{2}{*}{$\begin{array}{l}\text { Incubation } \\
\text { temperature } \\
\left({ }^{\circ} \mathrm{C}\right)\end{array}$} & \multicolumn{2}{|c|}{ DNA } \\
\hline & & $\begin{array}{c}\text { YCp } 19^{a} \\
\text { (Transformants/ } \\
\mu \mathrm{g} \text { ) }\end{array}$ & $\begin{array}{c}\text { LYTC- }^{b} \\
\text { (Transformants) }\end{array}$ \\
\hline \multirow[t]{2}{*}{ DKKAC2 } & 42 & 568 & 59 \\
\hline & 30 & 228 & 2 \\
\hline \multirow[t]{2}{*}{ DKKHr31 } & 42 & 1112 & 163 \\
\hline & 30 & 348 & 26 \\
\hline
\end{tabular}

a Closed circular DNA of plasmid YCp19 was isolated from the E. coli strain JM1097) and purified by $\mathrm{CsCl}_{2}$-ethidium bromide density gradient centrifugation as described. ${ }^{2)}$ Stock DNA solutions were diluted in Tris buffer and $10 \mu 1$ was used in the transformation experiment.

$b$ Plasmid LYTC-2 was extracted from yeasts by the $10 \mathrm{~min}$ procedure $\mathrm{e}^{6)}, 30 \mu 1$ of the aqueous layer was used in the transformation experiment.

c Two other strains (DKKHAS12, DKKHAS16; both MATa ura3-52) were poorly transformed by DNA of YCp 19 at $42^{\circ} \mathrm{C}$ giving 8 and 20 transformants per $\mu \mathrm{g}$ of DNA respectively.

Table II. Transformation Frequency by DNA OF YCp19 ISOLATED FROM E. coli JM1097) BY A RAPID Alkali Procedure ${ }^{8}$

\begin{tabular}{lcc}
\hline \multirow{2}{*}{ Strain } & \multicolumn{2}{c}{ Transformants $^{a}$} \\
\cline { 2 - 3 } & Fresh cells $^{b}$ & Stored cells $^{b}$ \\
\hline DKKHAC2 & 329 & 83 \\
DKKHr31 & 356 & 18 \\
\hline
\end{tabular}

a The DNA preparation was diluted 10 times in Tris buffer and then $10 \mu l$ was used in the transformation experiment.

b Yeast cells were incubated in YPAD plates ${ }^{5}$ at $30^{\circ} \mathrm{C}$ for 4 days (fresh) and then kept at $4^{\circ} \mathrm{C}$ for 30 days (stored).

resuspended in $200 \mu$ of the same buffer. Fifty $\mu 1$ samples were plated on SD medium ${ }^{5}$ containing $50 \mu \mathrm{g} / \mathrm{ml}$ of histidine, adenine, leucine, tryptophan, and lysine for the selection of $\mathrm{URA}^{+}$transformants.

The results presented in Tables $I$ and II demonstrate that whole cells simply incubated for $5 \mathrm{~min}$ in presence of lithium thiocyanate, divalent cations $\left(\mathrm{Ca}^{2+}, \mathrm{Mg}^{2+}\right)$, triacetin and PEG, were effectively transformed by DNA prepared by different procedures. The yield of transformants was markedly influenced by the temperature; incu- 
bation at $42^{\circ} \mathrm{C}$ increased the transformation frequencies $2 \sim 3$ fold with highly purified DNA of plasmid YCp19 and $7 \sim 30$ fold with plasmid LYTC-2 extracted from yeasts by a rapid procedure ${ }^{6)}$ (Table I). The transformation efficiency varied also with the DNA-host strain combination (Tables I and II). Table II shows that a high number of transformants was recovered with DNA isolated from Escherichia coli $\mathrm{JM} 109^{7}$ ) by a rapid alkali extraction procedure. ${ }^{8}$ Yeast cells kept for 30 days at $4^{\circ} \mathrm{C}$ were also transformed by crude plasmid DNA although with less efficiency (Table II).

To our knowledge, the procedure described here is the simplest so far reported for $S$. cerevisiae and it is potentially suitable for routine transformations of strains without the necessity of costly equipment, reagents, and time.

\section{References}

1) R. Rothstein, in "DNA Cloning Vol II: A Practical Approach" ed. by D. M. Glover, IRL Press, 1985, p. 45.

2) D. Keszenman-Pereyra and K. Hieda, Curr. Genet., 13, 21 (1988)

3) G. T. Marczynski and J. A. Jaehning, Nucl. Acids Res., 15, 8487 (1985)

4) G. M. Dani and V. A. Zakian, Proc. Natl. Acad. Sci. U.S.A., 80, 3406 (1983).

5) F. G. Sherman, G. R. Fink and J. B. Hicks, Laboratory Course Manual for Methods in Yeast Genetics, Cold Spring Harbor Lab., (1986).

6) C. S. Hoffman and F. Winston, Gene, 57, 267 (1987).

7) C. Yanisch-Perron, J. Vieira and J. Messing, Gene, 33, 103 (1985).

8) K. G. Hardy, in "Plasmids: A Practical Approach," ed. by K. G. Hardy, IRL Press, 1987, p. 1. 